\title{
HIV/AIDS- A GROWING EPIDEMIC IN PAKISTAN
}

\author{
Azhar Hussain ${ }^{1}$, Sheharyar Hussain², Syed Muhammad Ali3, Erah Ali', Aksa Mehmood 5 , Farwa Ali ${ }^{6}$ \\ ${ }_{1}^{1}$ Research Scholar, Department of Medicine, St. Matthew's University School of Medicine, Cayman Island. \\ ${ }^{2}$ Research Scholar, Department of Clinical Psychology, Teachers College, Columbia University: A Graduate School of Education, Health \\ \& Psychology, New York, U.S.A. \\ ${ }^{3}$ Research Scholar, Department of Biology, Stony Brook University, The State University of New York, New York, U.S.A. \\ ${ }^{4}$ Research Scholar, Department of Psychology, City College, The City University of New York, New York, U.S.A. \\ ${ }^{5}$ Research Scholar, Department of Biological Science, Queensborough Community College, The City University of New York, New York, \\ U.S.A. \\ ${ }^{6}$ Research Scholar, Department of Medicine, American University of Antigua School of Medicine, Antigua and Barbuda.
}

\section{ABSTRACT}

The Human Immunodeficiency Virus (HIV) is a global epidemic that impacts the lives of many individuals each year. There has been extensive research on HIV and AIDS, which allows the researcher to discover certain precautionary steps that can be taken as a means to reduce exposure. Some preventative measures presently recommended by reputable health experts and doctors consist of practicing safe sex, and participating in the frequent screening of blood specimens and other bodily fluids. The Institute for Health Metrics and Evaluation IHME at the University of Washington reports that Pakistan is at high risk of HIV/AIDS, and the number of cases has been steadily increasing since 1987. According to US National Library of Medicine, the total number of reported/confirmed cases of HIV/AIDS was 6, 000 in 2010 alone. Due to its fixed increase in prevalence, it is necessary to adopt certain protective measures as an attempt to impede HIV/AIDS from spreading further. This paper covers the causes and consequences of HIV/AIDS in Pakistan along with a discussion on the role of the Pakistani government in controlling this menace.

\section{KEYWORDS}

HIV, AIDS, Protected Sex, Life-Threatening Disease, Screening of Blood Specimen and Body Fluids.

HOW TO CITE THIS ARTICLE: Hussain A, Hussain S, Ali SM, et al. HIV/AIDS- a growing epidemic in Pakistan. J. Evolution Med. Dent. Sci. 2018;7(08):1057-1062, DOI: 10.14260/jemds/2018/240

\section{BACKGROUND}

The Human Immunodeficiency Virus (HIV) infection is becoming a prevalent disease in Pakistan, and its death toll has been steadily increasing each year since $1987 .{ }^{1}$ Although nearly 100, 000 individuals in Pakistan are living with HIV/AIDS, there are only 15, 370 documented individuals suffering from this illness. ${ }^{2}$ The number of HIV/AIDS infections in Pakistan has been increasing at an alarming rate; from 2005 to 2015, the number of reported infections in Pakistan increased from 8, 360 to 45, 990 cases, the highest global average increase of $17.6 \%$ in history. ${ }^{3}$ Furthermore, the death toll has also been on the rise. The University of Washington conducted a research study and found that the number of deaths caused by HIV/AIDS in Pakistan increased from 350 to a staggering number of 1, 480 between 2005 and 2015. This shows an average increase of $14.2 \%$ per year. 4

Antiretroviral therapy (ART), a drug regimen that helps treatment of the HIV/AIDS virus, 5 is not easily available in Pakistan; only a very small percentage of individuals suffering from HIV/AIDS receives ART drugs for treatment and prevention of HIV/AIDS. ${ }^{6}$ The first case of HIV/AIDS in

'Financial or Other Competing Interest': None.

Submission 30-01-2018, Peer Review 11-02-2018,

Acceptance 13-02-2018, Published 19-02-2018.

Corresponding Author:

Azhar Hussain,

St. Matthew's University,

School of Medicine,

Safe Haven Leeward 3,

Regatta Park, PO Box 32330,

Grand Cayman, KYI-1209, Cayman Islands.

E-mail: ahussain74@stmatthews.edu

DOI: $10.14260 /$ jemds $/ 2018 / 240$
Pakistan was reported in 1987, and since then, the number has been increasing rapidly according to the annual report of Pakistan National AIDS Control Program. ${ }^{1}$

There are many factors that are contributing factors to spreading HIV/AIDS virus in Pakistan, and these very factors posit a greater challenge for healthcare clinicians to fight the epidemic. Pakistan is one of the most densely populated countries in South Asia with a literacy rate of 54 percent.? Major reasons for this high population growth include lack of family planning and lack of use of contraceptives. Due to lack of education and cultural stigmas related to family planning, the treatment and prevention of HIV/AIDS becomes extremely difficult. ${ }^{8}$ The Khyber Pakhtunkhwa (KPK) health department reports that at least 6,853 patients with sexually transmitted diseases (STDs) were registered by 2015. Between 2011 and 2013, KPK saw 28, 865 patients with STDs; ${ }^{9}$ yet, there were rarely any individuals who sought treatment.

\section{SEXUALLY TRANSMITTED DISEASES}

Sexually transmitted diseases (STDs) are diseases or infections that are acquired through unprotected sexual intercourse, or oral sex and are caused by 30 different types of bacteria, viruses, and protozoa. ${ }^{10}$ While the only way to entirely prevent a STD from spreading is complete abstinence, there are numerous ways to prevent or decrease the probability of infection. Practicing safe sex by using condoms and having fewer partners are some methods to decrease the rate of transmission. ${ }^{11}$ Another prevention method is to ensure that one's partner is STD-free, by getting tested and attaining DNA reports. ${ }^{12}$ However, these tests are not entirely accurate, especially when detecting for more persistent viruses such as the human papilloma virus (HPV). Therefore, for optimal results, other vaccinations such as 
hepatitis A vaccine, hepatitis B vaccine, and HPV vaccine can be used for further protection and prevention. ${ }^{3}$

According to healthcare experts, people shy away from visiting the doctor when they find symptoms of STD on their genitalia. ${ }^{13}$ It is very important to have a routine exam or test for the doctors to find out whether or not the person is exhibiting signs of STDs. ${ }^{12}$ If infected patients do not come in early for checkups and their infections stay undiagnosed for a certain period of time, the likelihood of infertility significantly increases. ${ }^{14}$ Doctors cannot prevent people from having sexual relations, but they can educate them about safety measures, by informing them about using condoms and avoiding sexual contact if one of the partners is infected. ${ }^{3}$

\section{MENTALITY AND SITUATION OF PAKISTAN REGARDING HIV}

The prevalence of STDs is alarmingly high in Pakistan especially in male individuals. Currently, the STD rate in men in urban areas of Pakistan is estimated to be $8.5 \%$ in Karachi, $5.3 \%$ in Lahore, $4.0 \%$ in Faisalabad, $4.3 \%$ in Quetta, $2.5 \%$ in Rawalpindi, and $2.0 \%$ in Peshawar. ${ }^{15}$ The National AIDS Control Program conducted a study that found the infections rates to be as high as $60 \%$ amongst transgenders and $36 \%$ amongst the male sex workers. ${ }^{16}$

Low awareness about protection against this deadly disease in poor and middle-class areas is increasing the number of incidents of STDs. ${ }^{17}$ These STDs are known to facilitate the sexual transmission of HIV/AIDS infection. The most at risk populations for transmission of HIV/AIDS infection in Pakistan are people who inject drugs (PWID), transgender persons, males, and female sex workers with a rate of $27.2 \%, 5.2 \%, 1.6 \%$, and $0.6 \%$ respectively. 18 According to Fleming and Wasserheit, there is strong evidence that new patterns of drug use and shifts to injecting in particular is an important factor contributing to the rapid increase of HIV infection among drug users. ${ }^{19}$

While HIV symptoms generally appear 2-3 months after the sexual intercourse with an infected individual, AIDS symptoms may take many years to appear. ${ }^{19}$ Although it was first discovered in the 1980's in Africa, the United Nations AIDS (UNAIDS) representative reported that nearly 42 million people in the world are currently living with HIV/AIDS; while deaths due to the disease were over 3.1 million. ${ }^{20}$

\section{POVERTY}

According to the report by the Sustainable Development Policy Institute (SPDI), More than 58.7 million people in Pakistan are living below the poverty line. ${ }^{21}$ These individuals lack basic facilities such as, healthcare and education due to low family incomes. In addition, HIV/AIDS is culturally unacceptable in Pakistan and carries considerable amount of stigma. 22 The Pakistan Demographic Health Survey statistics indicates that Sindh Province has the highest prevalence rates out of all of the four provinces, with $490 \mathrm{HIV}$ and 84 AIDS cases, Punjab with 394 HIV and 43 AIDS cases, and KPK with 349 HIV and 53 AIDS cases. ${ }^{23}$ In rural Pakistani areas in particular, where there is a lack of awareness, people are ashamed to seek medical treatment; consequently, they face life-threatening consequences. This is, in part, due to a low literacy and a high poverty rate. ${ }^{7}$
There are many factors that make treatment of HIV/AIDS infections extremely challenging in Pakistan. These factors include: (1) widespread poverty; (2) significant power imbalances between men and women; (3) labor migration for jobs; (4) lack of medical resources to efficiently test the HIV positive person; (5) high level of drug use; (6) low condom usage rates; (7) low levels of awareness amongst health workers; and (8) use of syringes without sterilization. ${ }^{24}$ The average Pakistani makes $\$ 1513$ USD a year that means the average income is approximately $\$ 126$ USD per month. ${ }^{25}$ Due to socioeconomic constraints, individuals from lower and middle class lack basic knowledge about physical health. They are either not aware about or cannot afford to buy condoms in order to have prevent the transmission of any infections or diseases during sexual activity. ${ }^{26}$

Pakistan is a very conservative country with regards to discussion of one's sexual activities or family planning. ${ }^{7}$ Contraceptive commercials receive backlash from the country's religious and conservative bodies calling such advertisements "immoral" and against the religious norms of Islam. ${ }^{27}$ Pakistan Electronic Media Regulatory Authority (PEMRA) has also banned any advertisements about condoms. ${ }^{28}$ This conservative attitude of Pakistani authorities creates images in the minds of the public that protected sex and condom usage is a deviant act that is inappropriate to talk about. ${ }^{28}$ Experts say that the dramatic increase of STDs in Pakistan is due to unprotected sex. ${ }^{29}$ The UNAIDS Program representative also mentions that the poverty and denial of education plays a critical role in forcing women into becoming sex workers, which leads to a higher rates of STD transmission in Pakistan. ${ }^{30}$

\section{GENDER INEQUALITY IN PAKISTAN}

Gender inequality is also a key reason for the spread of HIV/AIDS in Pakistan. Women in Pakistan generally face discrimination due to their lower socio-economic status, lesser mobility, and low decision-making power as compared to Pakistani men, which leaves them vulnerable to HIV/AIDS. ${ }^{31}$ Due to gender inequality, the literacy rate for Pakistani women is only $35 \%$ compared to the literacy rate of $60 \%$ for Pakistani men. 32

\section{GOVERNMENTAL RESPONSE TO HIV/AIDS}

A few years ago, there was a commercial by a leading condom producing company promoting the use of condoms, the idea of protected sex, and the prospect of living better, healthier lives. The mere promotion of a contraceptive commercial stirred a significant controversy nationwide, and the PEMRA responded with banning the commercial immediately. ${ }^{28}$

In 2001, the Pakistani government developed a National HIV/AIDS Strategic Framework that established strategies for effective control of this deadly disease. ${ }^{4}$ In the following years, the government's biggest challenge was implementing this strategic plan, establishing effective partnerships, networking with the donors and NGOs, and neutralizing the stigma attached to HIV/AIDS. ${ }^{33}$ At least 45 non-governmental organizations (NGOs) were involved in the HIV/AIDS public awareness campaign. These NGOs supported and cared for the patients living with HIV; they focused on the population of sex workers in all four provinces of Pakistan. ${ }^{34}$ Although these NGOs are actively still working for the HIV/AIDS control in Pakistan, they are not enough in numbers to 
control prevalence of HIV/AIDS in growing population of Pakistan. ${ }^{35}$

\section{SEX EDUCATION IN SCHOOLS}

In western parts of the world, sex education is an important part of the school curriculum; school years are a critical time when young individuals become sexually active and they experiment with their sexuality. ${ }^{36}$ In Pakistan, however, young individuals do not receive sex education, because it is considered to be something that is very private and personal. Most parents do not educate their children or encourage them to attend any sex awareness programs. ${ }^{37}$ Children are generally told not to watch any advertisements that promote safe sex or condoms or contraceptives. 38

Conservative mind-sets usually prevail because Pakistan is a relatively religious Muslim majority country. ${ }^{22}$ It is considered unorthodox and unethical to educate children about protected sex practices and prevention of STDs in schools. ${ }^{37}$ Consequently, both children and adults exhibit little-to-no knowledge about safe sex, and the preventative measure that may be taken to prevent the spread of HIV/AIDS. ${ }^{39}$ If the government introduces sex education as a part of the curriculum in colleges and universities, it runs the risk of receiving a lot of backlash from the religious or conservative groups. 40

The Higher Education Commission (HEC) in Pakistan could make a strategic plan to visit every college and university annually to conduct seminars about HIV/AIDS, and aim to counsel and discuss its causes and its preventative measures. ${ }^{41}$ According to the Khandwalla, there is no harm in distributing condoms or contraceptives, along with a complete booklet or guide on HIV/AIDS amongst the students and the teachers and the staff. 42

\section{DRUG ABUSE}

In 2013, the Pakistan Bureau of Statistics in collaboration with the Narcotics Control Division, with the support of the United Nations Country Teams, conducted a national survey on drug use. The results of the household survey indicated that an estimated 860,000 or $0.8 \%$ of the population between the ages of 15 and 64 used heroin regularly, and 430,000 or $0.4 \%$ of people between the ages of 15 and 64 injected drugs. ${ }^{43}$ Among these, 78\% injected heroin and the remaining injected pharmaceutical opioids including morphine and other tranquilizers. In this survey, the majority reported injecting two to four times a day. ${ }^{44}$ According to the 2015 Spectrum, the number of people who inject drugs (PWID) was estimated at 104, 804. The concerns and issues of drug users are overlooked when it comes to national policymaking, planning, and implementation. In 2015, an association involving people living with HIV/AIDS was launched. 45 The association was a Drug Users Network whose mission was to involve influential and meaningful people as a means to influence policies, laws, programs, and funds; the association also involved drug users in attempts to make their voice heard. 46

The Opioid Substitution Therapy (OST) was recommended by World Health Organization and UNAIDS, which is yet to be introduced in Pakistan. ${ }^{47}$ Given that an estimate of 430, 000 individuals in Pakistan inject drugs; mostly opiates, it is very important to introduce OST.47 The Association of People Living with HIV/AIDS conducted a survey in 2013 and $2014,48.3 \%$ of people were reported to be arrested or detained for drug use. 45

\section{UNSAFE OR UNPROTECTED SEX}

Unprotected sex refers to an individual engaging in sexual activities (intercourse, etc.) without the use of a contraceptive such as condoms. 48 The exclusion of a condom during such engagements place the individuals involved at a high risk of HIV or STDs transmission.49 During an unprotected sexual activity, the HIV in the fluids, blood, or semen can transfer from one partner's body to another. In addition, alcohol overdose can create strong sexual desires in a person; which, in-turn, may lead to unprotected sex. ${ }^{50}$ However, Alcohol use may not be the main factor of unprotected sex. Thus, there should be a control on the sale and availability of alcohol. 51

Moreover, the price of the emergency contraceptive pill (ECP) and condoms also has no direct relationship with the decision to have protected sex. ${ }^{52}$ The prices of condoms like Touch and Sathi--Pakistani condom brands--are not costly when compared to US condom brands. The prices range from Rs. 10 PKR to Rs. 60 PRK, which is equivalent to a range from $\$ 0.10$ to $\$ 0.60$ USD. ${ }^{53}$ But since there is no knowledge, and awareness, people do not purchase and make use of these preventative measures that would benefit their health. 53 People appear to be unaware of the long-term pros and cons of using a contraceptive when engaging in sexual intercourse. ${ }^{7}$ There is no concept of family planning in Pakistani rural areas; the rural Pakistani families can be as large as seven to eight member families, while there is only one individual earning an income. ${ }^{54}$ If these lower classes are educated about the health benefits of using contraceptives before engaging in unprotected intercourse, the opportunity to prevent this deadly disease, will then start to be taken seriously. 55

\section{ETHICAL DILEMMAS}

When considering HIV/AIDs from an ethical viewpoint, it is necessary to recall the stigma, societal disapproval, and consent across cultures in response to this disease. This is more so important specifically in countries in which religion controls much of the influence, such as in Pakistan.56 Pakistan, being an Islamic state, has a population of people who consider the topic of HIV/AIDs, sexual encounters, and safe sex to be a taboo. While discussion of these topics is at a minimum, Pakistan continues to have a growing HIV/AIDs epidemic. In many Islamic societies HIV/AIDs is noted to be associated with homosexuality and promiscuity; however, it is essential to take note that HIV/AIDs can also arise from unsanitary blood transfusions and unprotected sexual intercourse. A reason as to why the Pakistani population is majorly misinformed in regard to the causes of the disease, is lack of education. Unethical protocols led by physicians in Pakistan is also a leading factor behind the general consensus that HIV/AIDs is a result of an individual's own actions, as opposed to actual pathology. Many HIV/AIDs patients in Pakistan share a similar experience in regard to their disease. One such individual is Shabnam who was diagnosed with HIV. When asked about her opinion on her diagnosis, Shabnam responded by saying that this disease seemed like it would be "the end of the world" for her. She mentioned that the social consequences for her condition brought her more fear than 
the disease itself. ${ }^{57}$ It is clear that this individual has experienced societal disapproval and condemnation as a result of her diagnosis. In order to prevent further cases in which a patient's perspective is influenced by cultural stigmas, it is necessary to properly educate the population about sexual education and to provide physicians with ample training to be able to handle these types of delicate situations.

\section{CONCLUSION}

The rise of Sexually Transmitted Diseases (STDs) has raised dire health concerns around the globe. Many steps are taken to contain the spread of STDs such as: (1) creating awareness programs; (2) encouraging protected sexual activity; (3) promoting the idea of sexual intercourse with a single-longterm trusted partner; and (4) screenings of blood and bodily fluids. 58 These STDs include, but are not limited to, diseases such as: HIV/AIDS, Genital Herpes, Syphilis, Gonorrhoea, etc. 59

While the most common cause of STDs is unprotected sexual intercourse, it may also spread through blood transfusion, saliva, and other body fluids. ${ }^{60}$ As demonstrated throughout this paper, Pakistan exhibits a low level of education regarding the topic of STD transmission, and preventative measures are immediately required in order to address the urgent situation of HIV/AIDS. This is largely associated with cultural norms in Pakistan (genderinequality, lack of communication regarding intercourse, etc.). Research suggests that these factors may be direct influences to the rise of HIV/AIDS cases (growth rate of approximately $17 \%$, death rate from HIV/AIDS approximately 15\%). ${ }^{61}$ Additional factors to include, but not be limited to, are low literacy rates (low literacy rates are intertwined with gender-inequality and cultural norms), and poverty (improper access and availability to medication and contraceptives/preventive measures), lack of early sex education through educational institutions, inability of government to implement strategic plan to create awareness and extend medical support to those that are suffering from the disease (thus preventing those that are vulnerable), religious conservative (often restricting people from gaining knowledge), media regulations (restricting non-profit and for-profit organizations), creating awareness through electronic and print media, drug abuse, and gender equality. 62 It is imperative that serious and immediate steps are taken to curtail the threat of HIV/AIDs in Pakistan and a multipronged approach with a heavy emphasis on education is carried out to successfully fight societal obstruction and negligence. ${ }^{63}$

\section{REFERENCES}

[1] Mujeeb AS, Hashmi MR. A study of HIV-antibody in sera of blood donors and people at risk. The Journal of Pakistan Medical Association 1988;38(8):221-2.

[2] Illicit drug trends in Pakistan. United Nations: Office on Drugs and Crime Country Office, Pakistan. The Paris Pact Initiative: a partnership to counter trafficking and consumption of Afghan opiates 2008. https://www.unodc.org/documents/regional/central asia/Illicit\%20Drug\%20Trends\%20Report_Pakistan_r ev1.pdf

[3] Khan AA, Khan A. Sexually transmitted infection care in Pakistan: the providers perspective. Journal of Pakistan Medical Assoication 2012;62(9):941-5. http://www.jpma.org.pk/full_article_text.php?article_i $\mathrm{d}=3678$

[4] Ghani A. HIV/Aids cases on the rise in Pakistan, says report. The Express Tribune. 2016. https://tribune.com.pk/story/1145390/flawedpolicies-hivaids-cases-rise-pakistan-says-report/

[5] Bhatti AB, Usman M, Kandi V. Current scenario of HIV/AIDS, treatment options, and major challenges with compliance to antiretroviral therapy. Cureus 2016;8(3):e515.

[6] Yusufzai A. Aids drugs access fraught with hazard for Pakistan's tribal regions. The Guardian. Guardian News and 2011. https://www.theguardian.com/globaldevelopment/2011/sep/12/access-hiv-aids-drugspakistan

[7] Tahir S. Injecting drug use and the risks of HIV infection: a case study of HIV and AIDS awareness in the red light district of Pakistan. $1^{\text {st }}$ edn. Saarbrücken: LAP Lambert Academic Publishing 2010.

[8] Bertozzi S. HIV/AIDS prevention and treatment. Disease control priorities in developing countries. $2^{\text {nd }}$ edn. 1970.

https://www.ncbi.nlm.nih.gov/books/NBK11782/

[9] Yusufzai A. Pakistan starts HIV treatment programme. BMJ 2006;332(7532):10.

[10] Shaukat S, Kazmi AH. Sexually transmitted infections and syndromic management. Journal of Pakistan Association of Dermatologists 2015;25(3):159-61. http://www.jpad.com.pk/index.php/jpad/article/vie wFile/102/83

[11] Farid-Ul-Hasnain S, Krantz G. Assessing reasons for school/college dropout among young adults and implications for awareness about STDs and HIV/AIDS: findings from a population-based study in Karachi, Pakistan. International Journal of Behavioral Medicine 2011;18(2):122-30.

[12] Centers for Disease Control and Prevention, Workowski KA, Berman SM. Sexually transmitted diseases treatment guidelines, 2006. MMWR Recomm Rep 2006;55(RR-11):1-94.

[13] Chan R. Sexually transmitted infections in Asia and the Pacific--an epidemiological snapshot. Sexually Transmitted Infections 2011;87(Suppl 2):ii14-5.

[14] Stangl A, Carr D, Brady L, et al. Tackling HIV-related stigma and discrimination in South Asia. World Bank, Washington DC: 2010 https://elibrary.worldbank.org/doi/abs/10.1596/978 -0-8213-8449-7

[15] Ilyas M, Asad S, Ali L, et al. A situational analysis of HIV and AIDS in Pakistan. Virology Journal 2011;8:191.

[16] Saleem NH, Adrien A, Razaque A. Risky sexual behavior, knowledge of sexually transmitted infections and treatment utilization among a vulnerable population in Rawalpindi, Pakistan. Journal of Pakistan Medical Association 2013;63(Suppl 1):S16S20.

http://www.jpma.org.pk/supplement_details.php?arti cle_id $=92$

[17] Ata-ur-Rehman K, Nighat $R$, Shakoor $K$, et al. Knowledge, attitudes and practices regarding blood 
donation among people from various areas in Karachi. National Journal of Health Sciences 2017;2(1):20-3.

[18] Faisel A, Cleand J. Migrant men: a priority for HIV control in Pakistan? Sexually Transmitted Infections 2006;82(4):307-10.

[19] Fleming DT, Wasserheit JN. From epidemiological synergy to public health policy and practice: the contribution of other sexually transmitted diseases to sexual transmission of HIV infection. Sexually Transmitted Infections 1999;75(1):3-17.

[20] Burn S, Horner PJ. Rectal gonorrhoea as an independent risk factor for HIV infection in homosexual males. Genitourin Med 1995;71(5):335-6.

[21] Sumra A. SDPI report: $58.7 \mathrm{~m}$ Pakistanis living below poverty line. The Express Tribune 2014. https://tribune.com.pk/story/675805/sdpi-report58-7m-pakistanis-living-below-poverty-line/

[22] Hasnain M. Cultural approach to HIV/AIDS harm reduction in Muslim countries. Harm Reduction Journal 2005;2:23.

[23] Han N, Wright ST, O'Connor CC, et al. HIV and aging: insights from the Asia Pacific HIV Observational Database (APHOD). HIV Medicine 2015;16(3):152-60.

[24] Mann MA, Hussain F, Jamil M. Prevalence and risk factors of HIV in Faisalabad, Pakistan- a retrospective study. Pakistan Journal of Medical Sciences 1969;30(1).

http://dx.doi.org/10.12669/pjms.301.4176

[25] Rana S. Per capita income: a Pakistani now makes \$1, 513 a year. The Express Tribune. 2015 https://tribune.com.pk/story/889024/per-capitaincome-a-pakistani-now-makes-1513-a-year/

[26] Qidwai W. Knowledge about sexually transmitted infections among young Pakistani men. Journal of Pakistan Medical Association 2002;52(6):267-8.

[27] Agha S. Intentions to use contraceptives in Pakistan: implications for behavior change campaigns. BMC Public Health 2010;10:450 http://dx.doi.org/10.1186/1471-2458-10-450

[28] Condom ads banned by Pemra DAWN.COM. 2016. https://www.dawn.com/news/1261217

[29] General health risks: sexually transmitted infections. IAMAT (International Association of Medical Assistance to Travellers). Country Health Advice Pakistan,

2016. https://www.iamat.org/country/pakistan/risk/sexual ly-transmitted-infections

[30] Stangl AL, Grossman CI. Global action to reduce HIV stigma and discrimination. Journal of the International AIDS Society 2013;16(3 Suppl 2):18934. http://dx.doi.org/10.7448/IAS.16.3.18881

[31] Farid-Ul-Hasnain S, Johansson E, Krantz G. What do young adults know about the HIV/AIDS epidemic? Findings from a population based study in Karachi, Pakistan. BMC Infectious Diseases 2009;9:38. http://dx.doi.org/10.1186/1471-2334-9-38

[32] Maan MA, Hussain F, Iqbal J, et al. Sexually transmitted infections in Pakistan. Annals of Saudi Medicine 2011;31(3):263-9.

[33] HIV seroprevalence surveys in Pakistan. HIV Seroprevalence Study Group of Pakistan. AIDS 1996;10(8):926-7.
[34] Hyder AA, Khan OA. HIV/AIDS in Pakistan: the context and magnitude of an emerging threat. Journal of Epidemiology \& Community Health. BMJ Publishing Group Ltd 1998;52(9):579-85. http://jech.bmj.com/content/52/9/579

[35] Waheed U, Azmat M, Arshad M, et al. HIV/AIDS epidemic and global health. Res Treat Open Journal 2016;2(4):105-7.

http://www.openventio.org/Volume2-Issue4/HIVAIDS-Epidemic-and-Global-Health-HARTOJ-2-118.pdf

[36] Sifferlin A. Why Schools Can't Teach Sex Ed Time. http://time.com/why-schools-cant-teach-sex-ed/

[37] Hyder AA, Khan OA, Memon MA, et al. Sub-national response in HIV/AIDS: a case study in AIDS prevention and control from Sindh province, Pakistan. Public Health 1999;113(1):39-43. http://www.publichealthjrnl.com/article/S00333506(99)00111-0/pdf

[38] Hunger KFH. Education at school about sexually transmitted diseases. Br J Vener Dis 1976;52(2):100-1. http://sti.bmj.com/content/52/2/100

[39] Otho SM, Perveen S, Abbas Q. FSWs typology and condoms use among hiv high risk groups in Sindh, Pakistan: a developing country perspective. Online Journal of Public Health Informatics 2013;5(1):e141. http://journals.uic.edu/ojs/index.php/ojphi/article/v iew/4481

[40] Yousaf MZ, Zia S, Babar ME, et al. The epidemic of HIV/AIDS in developing countries: the current scenario in Pakistan. Virology Journal 2011;8:401. https://virologyj.biomedcentral.com/articles/10.1186 /1743-422X-8-401

[41] Khan OA, Hyder AA. Responses to an emerging threat: HIV/AIDS policy in Pakistan. Health Policy and Planning 2001;16(2):214-8. https://academic.oup.com/heapol/articlelookup/doi/10.1093/heapol/16.2.214

[42] Khandwalla HE, Luby S, Rahman S. Knowledge, attitudes, and practices regarding sexually transmitted infections among general practitioners and medical specialists in Karachi, Pakistan. Sexually Transmitted Infections 2000;76(5):383-5 http://sti.bmj.com/content/76/5/383

[43] Drug Use in Pakistan 2013. United Nations: Office on Drugs and Crime Country Office, Pakistan. Ministry of Interior and Narcotics Control, 2013. https://www.unodc.org/documents/pakistan/Survey _Report_Final_2013.pdf

[44] Population research and policy development in Pakistan. Population Association of Pakistan-Statistics. PAP, 2003.

http://www.pap.org.pk/publications/Proceedings200 3.htm

[45] Bergenstrom A, Achakzai B, Furqan S, et al. Drugrelated HIV epidemic in Pakistan: a review of current situation and response and the way forward beyond 2015. Harm Reduction Journal 2015;12:43. https://harmreductionjournal.biomedcentral.com/art icles/10.1186/s12954-015-0079-5 
[46] Abbasi K. Focus on South Asia--II: India and Pakistan. British Medical Journal 1999;318(7191):1132-5. http://www.bmj.com/content/318/7191/1132

[47] Farid-ul-Hasnain S, Johansson E, Gulzar S, et al. Need for multilevel strategies and enhanced acceptance of contraceptive use in order to combat the spread of HIV/AIDS in a Muslim society: a qualitative study of young adults in urban Karachi, Pakistan. Global Journal of Health Science 2013;5(5):57-66. http://www.ccsenet.org/journal/index.php/gjhs/artic le/view/26715

[48] Shah N. Unsafe sex: migrant workers put native communities at risk of HIV. The Express Tribune 2013. https://tribune.com.pk/story/521891/unsafe-sexmigrant-workers-put-native-communities-at-risk-ofhiv/

[49] Hasnain SF, Johansson E, Mogren I, et al. Young adults' perceptions on life prospects and gender roles as important factors to influence health behaviour: a qualitative study from Karachi, Pakistan. Global Journal of Health Science 2012;4(3):87-97. http://www.ccsenet.org/journal/index.php/gjhs/artic le/view/13323

[50] Alcohol overdose: the dangers of drinking too much. National Institute on Alcohol Abuse and Alcoholism, U.S. Department of Health and Human Services. https://pubs.niaaa.nih.gov/publications/alcoholoverd osefactsheet/overdosefact.htm

[51] Alcohol can induce us to have unsafe sex. Pakistan News. One Pakistan: One people one Nation: 2011. http://pakistan.onepakistan.com.pk/news/health/25 653-alcohol-can-induce-us-to-have-unsafe-sex.html

[52] Rizvi N, Khan KS, Shaikh BT. Gender: shaping personality, lives and health of women in Pakistan. BMC Women's Health 2014;14:53. https://bmcwomenshealth.biomedcentral.com/article s/10.1186/1472-6874-14-53

[53] Emergency contraceptive pill use. The Nurse Practitioner 1997;22(11) http://journals.lww.com/tnpj/Citation/1997/11000/ Emergency_Contraceptive_Pill_Use_.4.aspx
[54] Dil AS. Missing HIV kits in Pakistan. The Lancet 2001;358(9285):923.

http://dx.doi.org/10.1016/S0140-6736(01)06049-4

[55] Sexually Transmitted Diseases SACHET Pakistan. Society for the Advancement of Community, Health, Education and Training. http://sachet.org.pk/sexually-transmitted-diseases/

[56] Athar S. Sex education, teenage pregnancy, sex in Islam and marriage. Islam-USA - sex education, Teenage Pregnancy, Sex in Islam and marriage. 2017. http://islam-

usa.com/index.php?option=com_content\&view=articl e\&id=289\&Itemid=301

[57] Daily Times -Your Right to Know. Contemplating Suicide: The ordeal of women living with HIV in Pakistan.

2016.

http://dailytimes.com.pk/features/18-Oct-

16/contemplating-suicide-the-ordeal-of-women-

living-with-hiv-in-pakistan

[58] Farid-ul-Hasnain S. Young adults in urban Pakistan: barriers and challenges for improving health behaviors in the wake of the HIV/AIDS epidemic. Division of Global Health (IHCAR), Department of Public Health Sciences, Karolinska institute, $1^{\text {st }}$ edn. Stockholm: 2010.

[59] Hashemi-Shahri SM, Sharifi-Mood B, Kouhpayeh HR, et al. Sexually transmitted infections among hospitalized patients with Human Immunodeficiency Virus infection and Acquired Immune Deficiency Syndrome (HIV/AIDS) in Zahedan, Southeastern Iran. International Journal of High Risk Behaviors \& Addiction 2016;5(3):e28028.

[60] Moazzam A, Ushijima H. Emerging role of the private sector in HIV/AIDS disease prevention in Pakistan. Tropical Doctor 2004;34(3):189-90.

[61] Pakistan. World Health Organization. 2017. http://www.who.int/countries/pak/en/

[62] Narain JP. Three decades of HIV/AIDS in Asia. 1st edn. New Delhi: SAGE Publications 2012.

[63] Farooq U. Let's talk about STDs. The Express Tribune 2015. https://tribune.com.pk/story/1013468/letstalk-about-stds/ 